Special issue of the 3rd International Conference on Computational and Experimental Science and Engineering (ICCESEN 2016)

\title{
Effect of Welding Current and Time on Tensile-Peel Loading in Resistance Spot Welding of SPA-H Steel Sheets Used in Railway Vehicles
}

\author{
N. AKKAS \\ Sakarya University, Faculty of Technical Education, Sakarya, Turkey
}

\begin{abstract}
This paper presents an experimental study on resistance spot welding of SPA-H weathering steel sheets used in side wall and roof application of rail vehicle bodies. SPA-H steel sheets having $2.3 \mathrm{~mm}$ thicknesses were joined by using resistance spot welding as lap joint. A timer and current controlled resistance spot welding machine having $120 \mathrm{kVA}$ capacity and a pneumatic application mechanism with a single lever was used to prepare the specimens. Welding periods were chosen as 10, 15, 20, 25, and 30 periods ( 1 period $=0.02 \mathrm{~s})$ and also welding currents were increased from $6 \mathrm{kA}$ up to $11 \mathrm{kA}$ by rise of $0.5 \mathrm{kA}$. The electrode force was kept constant at $4 \mathrm{kN}$. The prepared welding specimens were exposed to tensile-peel test and the obtained results were supported by diagrams and, finally, appropriate welding current and time were advised to the users.
\end{abstract}

DOI: 10.12693 /APhysPolA.132.549

PACS/topics: resistance spot welding, tensile-peel loading, weathering steel sheets

\section{Introduction}

Weathering steels, also known as low-alloy steels, are mild steels with a carbon content of less than $0.2 \mathrm{wt} \%$, to which mainly $\mathrm{Cu}, \mathrm{Cr}, \mathrm{Ni}, \mathrm{P}, \mathrm{Si}$, and $\mathrm{Mn}$ are added as alloying elements totalling a few percent maximum [1].

In the 1920s US Steel produced a new family of HSLA steels intended primarily for the railway industry. In 1933 US Steel launched the first commercial weathering steel under the brand name USS Cor-Ten steel. This product was claimed to provide a $30 \%$ improvement on the mechanical properties of conventional carbon steel, thus reducing the necessary thickness and accordingly the weight of steel to be used for a given set of mechanical requirements [2].

SPA-H weathering steels or, in other words, superior atmospheric corrosion resistant steels are applied to rolling stock body, architecture, steel tower, marine containers, container, bridges, and other structures.

Resistance spot welding (RSW) is a joining process in which coalescence of the metal sheets is produced at the faying surface by the heat generated at the joint by the resistance of the work to the flow of electric current [3, 4]. By applying a suitable welding time, the current and the electrode force a sufficient nugget size and shape may be created within ms [5]. Because the processes require relatively simple equipment, it is easily and normally automated and once the welding parameters are established it should be possible to produce repeatable welds, the resistance spot welding is the most widely used joining process for sheet materials [6]. RSW is widely used in rolling stock and automotive industries. Typically, there are about 2000-5000 spot welds in a modern vehicle [7].

*e-mail: akkas.nuri@gmail.com
Like any other welding processes, the quality of the joint in RSW is directly influenced by welding input parameters. In most cases, good spot-welding practice requires three parameters that have to be controlled, namely, current, time, and electrode force [8]. A common problem faced by manufacturer is the control of the process input parameters to obtain a well welded joint with required strength. Each spot welding is not performed on the same condition because of the alignment of sheets and electrodes as well as the surface condition $[9,10]$.

Welding current and time are directly proportional to the amount of heat being generated. Increased welding current and time result in increased heat generation. It facilitates nugget growth which enhances the mechanical performance of weldments. However, excessive welding current and time results in expulsion due to nugget overgrowth. This can introduce weld defects into the weldment, such as voids and excessive indentation, which adversely affects weld performance $[11,12]$.

In order to obtain optimum welding parameters, such as the welding current and the time, and thereby to ensure a good quality of the spot welds, testing for the mechanical properties is essential. For this, a number of techniques has been developed, including both destructive and non-destructive methods. Among the most commonly used destructive (mechanical) tests are the crosstension test, the tensile peel test, and the tensile shear test [5]. The tensile-peel strength of the joint in resistance spot welding is an important index to welding quality [13].

Therefore, in this study the relationship between welding parameters and tensile-peel strength of joint in SPA$\mathrm{H}$ weathering steel sheets in resistance spot welding was investigated. The samples were exposed to tensile-peel tests in order to determine the joint strengths. The effect of welding current and time on tensile peel strength was determined by using related diagrams and the optimum welding currents and times were advised. 


\section{Experimental studies}

The sheets were welded by RSW by fixing electrode form, type of materials, cooling water flow rate and electrode force as well as changing welding current and welding time. All series were exposed to tensile peel tests in order to determine the joint strengths.

\subsection{Materials}

The materials studied are SPA-H steel sheets having $2.3 \mathrm{~mm}$ thicknesses, which are used in side wall and roof application of rail vehicle bodies. The chemical composition and the mechanical properties of the sheet are, respectively, shown in Tables I and II.

TABLE I

Chemical composition of steel sheets used in experiments [wt\%].

\begin{tabular}{c|c|c|c|c|c|c|c|c}
\hline \hline $\mathrm{C}$ & $\mathrm{Si}$ & $\mathrm{Mn}$ & $\mathrm{P}$ & $\mathrm{S}$ & $\mathrm{Al}$ & $\mathrm{Cu}$ & $\mathrm{Cr}$ & $\mathrm{Ni}$ \\
\hline 0.081 & 0.419 & 0.426 & 0.084 & 0.006 & 0.031 & 0.315 & 0.664 & 0.328
\end{tabular}

TABLE II

Mechanical properties of the sheet steel.

\begin{tabular}{c|c} 
yield strength [MPa] & 457 \\
tensile strength [MPa] & 572.7 \\
total elongation [\%] & 40
\end{tabular}

\subsection{Welding equipment}

A timer and current controlled RSW machine having $120 \mathrm{kVA}$ capacity and pneumatic application mechanism with a single lever were used in the experiments. The electrode force was continuously measured and controlled during the experiments. Also welding current values were continuously calculated and controlled by means of a current transformer which is set up on the lever of welding machine and an ampere-meter. Weld time, hold time, and clamping time were adjusted automatically by electronic devices of the machine. Welding was carried out by using water cooled conical $\mathrm{Cu}-\mathrm{Cr}$ electrodes having a contact surface of the same diameter diameter $(8 \mathrm{~mm})$ in accordance with EN ISO 5182 [14].

\subsection{Welding process and tensile-peel strength}

The specimens were overlapped and welded in accordance with EN ISO 14373 as shown in Fig. 1 [15]. The electrode force was fixed at $4 \mathrm{kN}$ and controlled during experiments. The welding time was applied as 10, $15,20,25$, and 30 periods (per). Clamping and hold times were remained constant as 25 per in all series. The welding current was increased from $6 \mathrm{kA}$ to $11 \mathrm{kA}$ by $0.5 \mathrm{kA}$ increments. Therefore, different welds joint properties were obtained. The welded parts were exposed to tensile-peel tests in a testing machine in laboratory conditions. The tensile speed was remained constant during test. The values given as tensile-peel strength are the maximum values read from the scale of the machine. The dimensions of the tensile peel specimens are shown in Fig. 2.

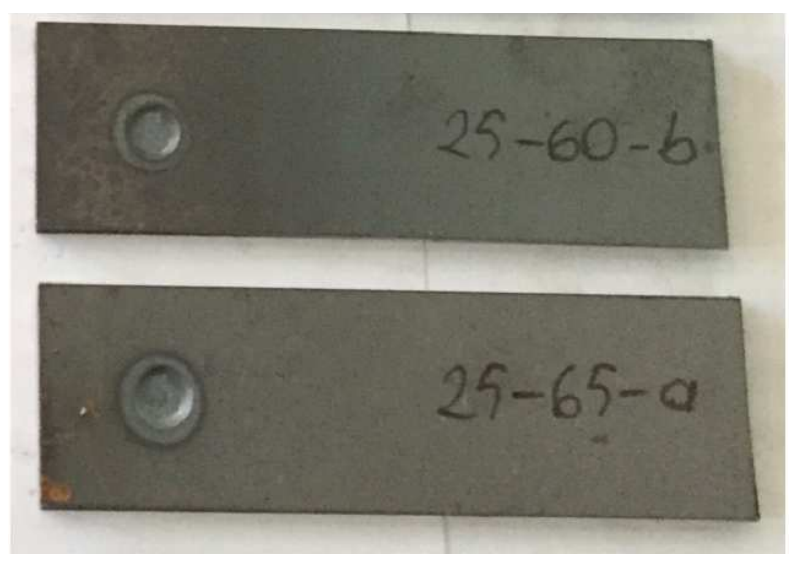

Fig. 1. Specimen welded by resistance spot welding.

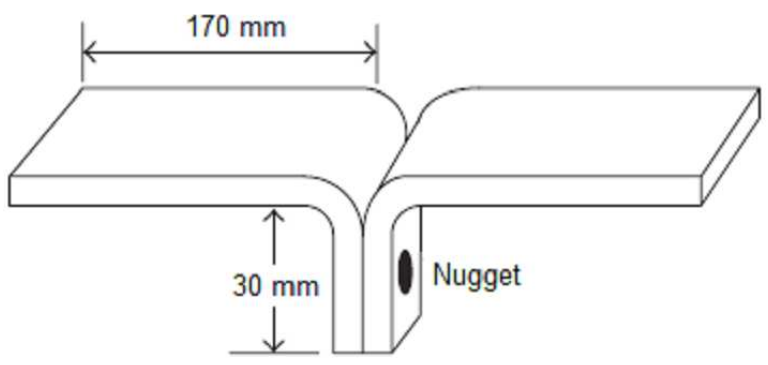

Fig. 2. The dimensions of the tensile peel specimens.

\section{Results}

In the light of results obtained from diagrams in Figs. 3 and 4, increasing welding current and time cause high heat input to weld zone and extending weld nugget, so the tensile-peel strength of joints increases.

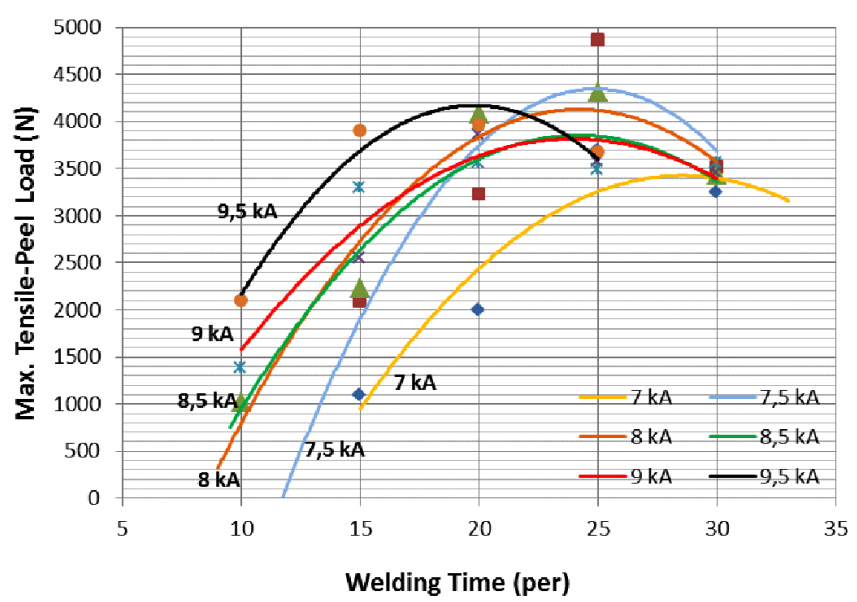

Fig. 3. Effect of welding time on tensile-peel load of weld joints.

At $7.5,8$, and $8.5 \mathrm{kA}$, tensile-peel strengths of specimens increase sharply up to 20 per and then this increment continues with a lower rate. At $9 \mathrm{kA}$ and $9.5 \mathrm{kA}$ welding current, tensile-peel strengths of specimens in- 


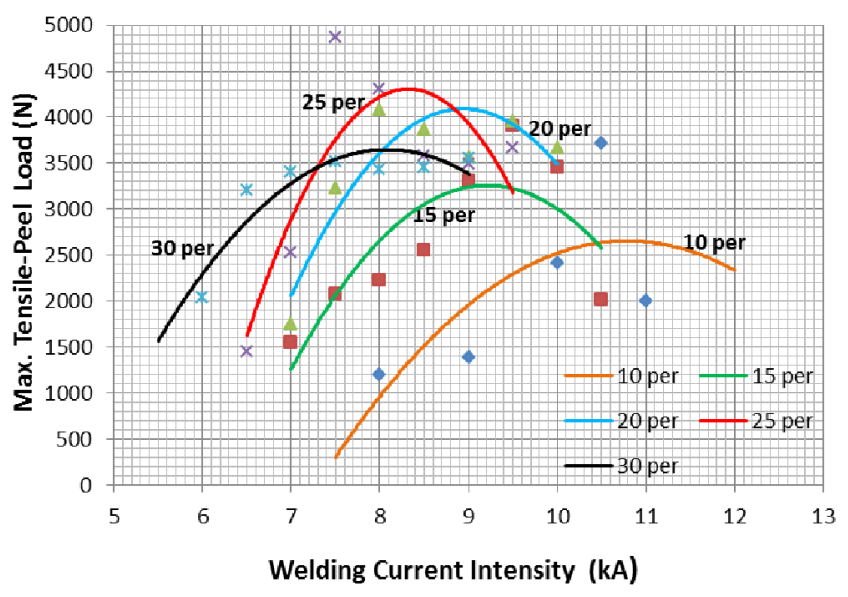

Fig. 4. Effect of welding current on tensile-peel load of weld joints.

crease up to 20 per where the maximum point is for this current. The maximum tensile-peel strength is obtained in 25 per for $7.5 \mathrm{kA}$ welding current.

In low welding current application, small weld nugget diameters were obtained and similarly lower tensile peel strength value than that of base-metal was measured due to low heat application to welding zone. As a result, break type was observed as separation. However, the tensile-peel strength increases with increasing weld current. Therefore, break type was observed as knotting and tearing [16-21]. During the tensile-peel tests, three types of breaking failure were observed: separation, knotting, tearing. Samples of them are shown in Fig. 5.

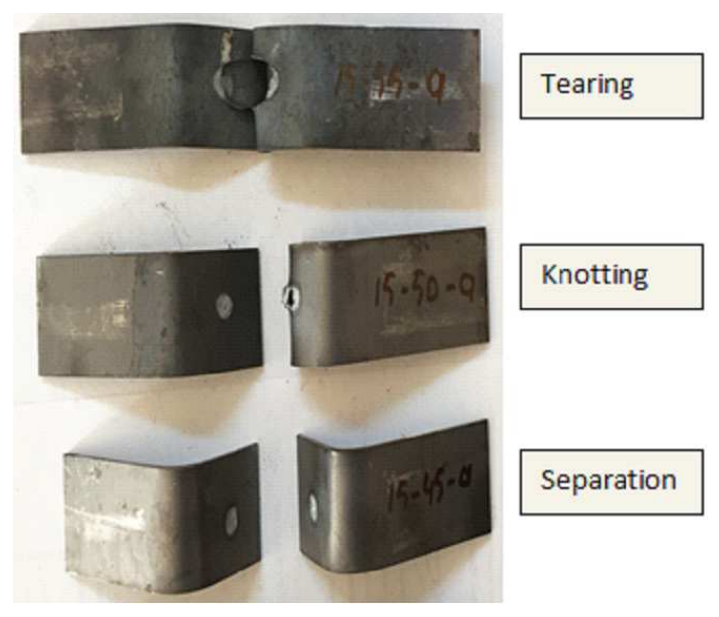

Fig. 5. Breaking failure samples observed in tensilepeel tests.

In long welding time and high welding current application, cross-section area decreases, as a result, tensilepeel strength of joint decreases. Electrodes react to work piece due to excessive heating of them which cannot be compensated by cooling water.

In addition, weld nugget spurts out between two sheets resulting in the decrease in diameter. This may be a

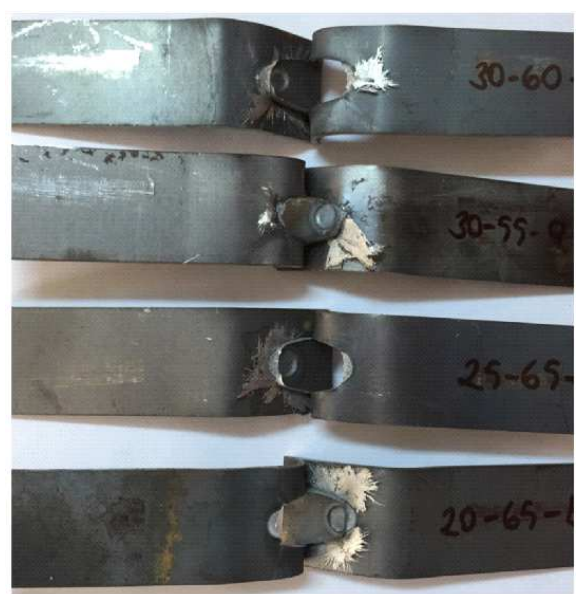

Fig. 6. Spurt out failure observed in weld nuggets.

reason for decreasing trend of tensile-peel strength shown in Fig. 6. At the same time, an over-coloured, retained structure with deep electrode marks and deformations was determined in weld zone.

\section{Conclusion}

As a result of the work performed at $4 \mathrm{kN}$ electrode force, the obtained results and some suggestions are given below.

In the joining of SPA-H steel sheets, maximum tensile peel strength is obtained at $7.5 \mathrm{kA}$ welding current, at 25 period.

When the high surface quality is more important than strength, $7 \mathrm{kA}$ welding current for 30 period welding time or $8 \mathrm{kA}$ welding current for 20 period welding time are enough. The depth of electrode indentation into the material has not exceeded the $30 \%$ of sheet thickness limit, which is accepted for a good surface quality.

Increasing welding current and time cause high heat input to weld zone and extending weld nugget, so the tensile-peel strength of joints increases.

In low welding current and time, small weld nugget diameters were obtained and similarly lower tensile-peel strength value than that of base-metal was measured due to low heat application to welding zone. However, in high welding current and time, cross-section area decreases. Weld nugget spurts out between two sheets resulting in the decrease in nugget width.

\section{References}

[1] T. Murata, in: Uhlig's Corrosion Handbook, 2000, p. 569 .

[2] M. Morcillo, B. Chico, I. Díaz, H. Cano, D. Fuente, Corros. Sci. 77, 6 (2013).

[3] Z. Han, Ph.D. Thesis, Illinois University, 1992.

[4] Welding Handbook, 8th ed., Vol. 2, Welding Processes, American Welding Society, 1997.

[5] K.L. Nielsen, V. Tvergaard, Eng. Fract. Mech. 77 , 1031 (2010).

[6] A. Hasanbasoglu, R. Kacar, Mater. Des. 28, 1794 (2007). 
[7] F. Khodabakhshi, M. Kazeminezhad, A.H. Kokabi, Mater. Character. 69, 71 (2012).

[8] A.M. Al-Mukhtar, Q. Doos, Adv. Mater. Sci. Eng. 2013, 1 (2013).

[9] S. Aslanlar, A. Ogur, U. Ozsarac, E. Ilhan, Z. Demir, Mater. Des. 28, 2 (2007).

[10] S. Aslanlar, A. Ogur, U. Ozsarac, E. Ilhan, Mater. Des. 29, 1427 (2008)

[11] S. Aslanlar, Mater. Des. 27, 125 (2006).

[12] M.I. Khan, Ph.D. Thesis, University of Waterloo, 2007.

[13] S.M. Hamidinejad, F. Kolahan, A.H. Kokabi, Mater. Des. 34, 759 (2012).

[14] Turkish Standards Institution, Resistance welding Materials for electrodes and ancillary equipment, TS EN ISO 5182, 2010.
[15] Turkish Standards Institution, Resistance welding Procedure for spot welding of uncoated and coated low carbon steels, TS EN ISO 14373, 2008.

[16] N. Akkaş, E. Ilhan, F. Varol, S. Aslanlar, Mater. Test. 56, 879 (2014).

[17] N. Akkas, E. İlhan, Acta Phys. Pol. A 125, 497 (2014).

[18] N. Akkas, F. Varol, E. Ferik, E. İlhan, U. Ozsarac, S. Aslanlar, Acta Phys. Pol. A 125, 500 (2014).

[19] N. Akkas, E. Ilhan, F. Varol, S. Aslanlar, Acta Phys. Pol. A 129, 541 (2016).

[20] N. Akkaş, E. Ferik, E. İlhan, S. Aslanlar, Acta Phys. Pol. A 130, 142 (2016)

[21] N. Akkaş, E. Ferik, E. İlhan, S. Aslanlar, Acta Phys. Pol. A 130, 60 (2016). 